\title{
Praxis of Building and Using a Virtual Learning Environment
}

\section{Vladimir Burcik University of SS Cyril and Methodius in Trnava, Trnava, Slovakia}

\author{
Robert Joseph Skovira \\ Robert Morris University, \\ Moon Township, PA, USA
}

\author{
vladimir.burcik@ucm.sk
}

\author{
skovira@rmu.edu
}

\begin{abstract}
Our faculty continuously works on implementing new methods of teaching to our learning programs. In the framework of the project "Design and application of the e-learning courses" we have developed e-learning logistic and content for the doctoral students. In the preliminary phase, we tested the possibilities of the virtual class as a tool for efficient online transmission of the content. We have tested Elluminate, Wiziq, Wimba classroom and Sclipo. We tried to find answers to questions regarding technology parameters, quality of Internet connections but also the experience of teachers and students while using it. Our experience shows that progress is remarkably fast and technology is much more reliable as before. The continuous problems are on the user side. Content and context are still crucial. This is the main reason why e-learning is considered a long-distance race.

From May, 1st 2010 a team at the Faculty of Mass-Media Communication has started to work on a new curriculum - Media Relations in English language. The output of the project will be the foundation of a new accreditation based on a standardized curriculum with a well defined subject matter and teaching pedagogy. The launch of the new programme could happen in the academic year 2012/2013 after approval of the accreditation. The project is funded by the European Union.

The aim of the project is implementation new form of education into the study process. It means to design, and put into function an e-learning system of education for doctoral study in the field of Mass-media Studies and. study programs Mass-media Communication and Marketing Communication. The study will start at the beginning of the year 2013, after finishing the preparation phase of the project. Finally, we will create a modular base for the next development of e-learning study for the faculty. In the first stage of this project, besides building the structure and content of the courses, we will complete preliminary comparative analyses of the Learning Management Systems (hereinafter LMS), e-learning authoring tools, and also test e-learning applications and vir-

Material published as part of this publication, either on-line or in print, is copyrighted by the Informing Science Institute. Permission to make digital or paper copy of part or all of these works for personal or classroom use is granted without fee provided that the copies are not made or distributed for profit or commercial advantage AND that copies 1) bear this notice

tual classrooms in a "live" teaching environment. The project is also funded by the European Union. This article will proceed to share our experiences and practices realized from the first phase of the project.
\end{abstract} in full and 2) give the full citation on the first page. It is permissible to abstract these works so long as credit is given. To copy in all other cases or to republish or to post on a server or to redistribute to lists requires specific permission and payment of a fee. Contact Publisher@InformingScience.org to request redistribution permission. 
Keywords: e-learning, e-course, virtual class, Wiziq, Wimba classroom, Elluminate, Blackboard, managing of e-learning projects, Learning Management Systems, e-learning authoring tools.

\section{Biographies}

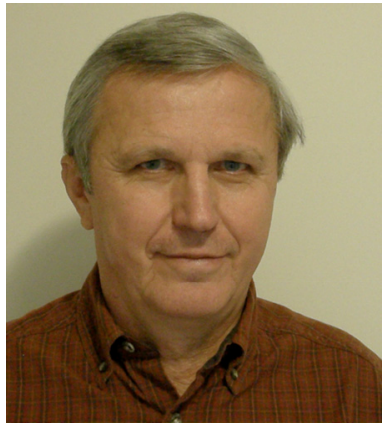

Vladimír Burčík. Project manager and e-learning designer at Faculty of Mass Media Communication, University of SS. Cyril and Methodius in Trnava, Adjunct Professor and Middle Europe Consultant, School of Communication and Information Systems, Robert Morris University, Pennsylvania, USA. He gives lectures at the FMC UCM, at the Department of Psychology at the Faculty of Arts, Comenius University, at the Department of Design at the Academy of Fine Arts and at the Department of Computer and Information Systems at the RMU. Vladimir Burcik is the member of European Academy of Digital Media. He is involved in World Summit on Information Society Award as a Member of the Board of Directors (2002-2007 and as National Eminent Expert (from 2007)

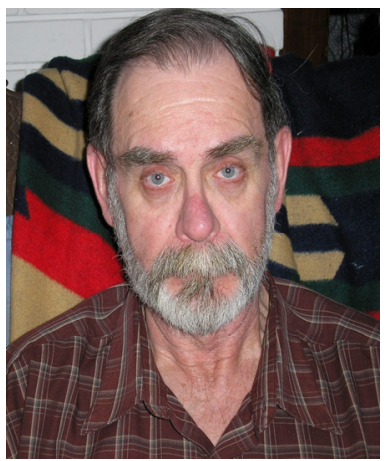

Robert Joseph Skovira is University Professor of Computer and Information Systems in the Department of Computer and Information Systems at Robert Morris University, Moon Twp (Pittsburgh) PA USA. He has taught undergraduate and graduate (MS) courses including Java Programming, Secure Programming, Global, Economic, Social, and Ethical Issues of Computing, Decision Support Systems, Information Design, and Ethical and Legal Issues of Technology. In the Doctor of Science program, he has taught Ethnography of Information Systems, Readings in Information Systems and Communications Research, and Writing the Proposal for Research courses. He has been a visiting professor at Comenius University, Bratislava, Slovakia, in 1997 and 2006. Research interests include the anthropology of information, information and information system use within organizations (the infoscape, politics of information, information system bias), cultural and moral frameworks of information and information use, decision making and knowledge management, informing objects, information design and thinking visually. 